\title{
Gender-based Religious Democracy: A Study of Umi Azizah's Winning and Women Political Movement of Tegal Regent Election in 2018
}

\author{
Zaki Mubarok ${ }^{{ }^{*}}$ \\ ${ }^{1}$ Bakti Negara Islamic High School, Tegal, Indonesia
}

\begin{abstract}
The winning of Umi Azizah as a Tegal Regent in the period of 2018-2023 describes the achievement of the democracy which tends to be religious in Tegal. She is the first woman regent in the history of Tegal Regency. Before that, in the period of 2013-2018, she acted as the Vice Regent of Ki Enthus Susmono in leading Tegal Regency. WTP opinion was achieved by Tegal Regency after waiting for 13 years. In June 2018, Umi Azizah got $70 \%$ votes, she is chosen as the Tegal Regent after replacing Ki Enthus Susmono who passed away. Before dying, in the occasion of Halaqoh of 999 Ulama in Tegal regency, Ki Enthus said that if in the period of 2018-2023 Umi Azizah steps forward to be the candidate of Tegal Regent, then Ki Enthus will not be against her. Moreover, Ki Enthus said that he will be her supporter. In spite of her position as a political figure, Umi Azizah is also the leader of Muslimat NU (Autonomous Organization in NU) in Tegal regency. She has a strategic position as the majority of Tegal residents are Moslem and affiliated to NU. This article describes the power of Umi Azizah as a woman who is chosen to be a regent, builds political connections, and also faces political escalation with religious doctrinal campaign which has a gender bias.
\end{abstract}

\section{Introduction and Literature Review}

The interesting phenomenon in the Tegal Regent Election discussed in this article is based on the transitional condition, in which Umi Azizah as the candidate of Vice Regent replacing Ki Enthus Susmono as the candidate of Tegal Regent on Tuesday, May14 2018 at 07.15 p.m. Ki Enthus Susmono then passed away. This condition caused a critical change in the political situation in which Umi Azizah appeared as a replacement for Ki Enthus Susmono as the candidate of Tegal Regent and Sabilillah Ardie as the candidate of Tegal Vice Regent. This replacement was not only initiated by $P K B$ as the supporting party, but also involving NU Tegal. In NU Tegal, Umi Azizah is the chief of Muslimat NU, an autonomous organization in NU which deals with the movement of female participants in this organization. Because of this, NU felt responsible to secure its participant in the Tegal Regent Election. Not only PKB as a party, the role of NU which has some autonomous organizations and its cultural strength was also set to support Umi Azizah-Sabilillah Ardie. NU moved massively in every village in Tegal to support this couple.

NU defines the electoral democracy as a religious way which has an effort to gain peace and love in the universe [1]. Institutionally, NU Tegal does not matter if a woman becomes a leader. In the cultural area, akar rumput, the NU members also support Umi Azizah

\footnotetext{
*Corresponding author: zakimubarok862@gmail.com
} 
massively as the candidate of Tegal Regent. At this point, the thought and movement of NU which is known as a traditional organization transformed quickly in responding the religious and political dynamics. NU accepts the paradigm that a woman becoming a leader in politics or country is a necessity. It is something that is rarely perceived by traditional organization in the world. The most excitement from this political dynamics is the winning of Umi Azizah with the result of the votes reaching 70,94\%.

As the preliminary study, the writer joined some events, in which the electoral democracy element existed, which are held by NU Tegal. One of these events was the plenary meeting of NU Tegal, which was attended by the regency administrators, districts administrators, and the administrators of the autonomous organizations, on January $8^{\text {th }}$ 2018. At that time, the couple of Enthus-Umi was declared by $P K B$ and supported by NU Tegal. Another review is the observation of Halaqohof 999 Ulama on May $6^{\text {th }}$ 2018. In that occasion, NU Tegal restated that the institution supported Enthus-Umi couple as the candidate of Regent-Vice Regent of Tegal. On May $14^{\text {th }} 2018$, this couple faced a crucial phase because Ki Enthus Susmono passed away on that day.

Halal bi halal event of NU Tegal which was held on June $18^{\text {th }} 2018$ is a momentum to restate the idea that Umi Azizah is a suitable replacement for Ki Enthus Susmono who has similar thoughts, dreams, and spirits. At that time, Umi Azizah had been appointed to be with Sabilillah Ardie.

This preliminary study describes that the democracy in Tegal is not without any religious values. On the contrary, Islam which is represented by NU becomes a base in the process of democracy. It supports gender equality by supporting Umi Azizah as a political leader.

\subsection{Gender Internalization of Women Political Movement in Tegal Regent Election}

The election of Tegal Regent was followed by three couples of candidate. The first couple is Rusbandi-Fatkhudin (8,79\% votes), the second is Bagas Prakoso-Drajat (20,27\% votes), and Umi Azizah-Sabilillah Ardie (70,94\% votes) [2]. As the only female candidate, Umi Azizah not only has a special attraction, but also has a resistance which cannot be underestimated. The rivalry using gender issue is often done to criticize female leadership in the name of Islamic rule. "Lanang bae.. Lanang bae...", is an example. This sentence is created by Umi Azizah's political rival. The sentence is a device to attack her by explaining that a woman is not appropriate to be a political or governmental leader so that a male candidate is more appropriate to be voted. Social media networking was massively used as a campaign medium against gender. However, NU as the institution does not matter with the female leadership. It is proven by the fact that in the period of 2013-2018, Umi Azizah was the Vice Regent accompanying the Regent, Ki Enthus Susmono. At this point, NU is, indeed, an institution which has gender equality.

Gender is defined as "mental and cultural interpretation toward the differences of sex, i.e. man and woman. It is usually used to show job descriptions which are considered appropriate for male or female." ${ }^{[3]}$ Gender appreciation is very urgent in egalitarian society. If a social situation cares about womanly and manly situation with the spirit of balance as well as social change, the social-political stratum of women will get better. On the contrary, putting women in an imbalance situation will make them getting worse.

Gender, as described by Oakley (1972) in Sex, Gender, and Society, is defined as the differences which do not deal with biological differences and God's natures. Biological differences are the differences of being men and women. God's natures are the differences which are permanently different related to destiny. Meanwhile, gender is the difference of 
behaviour/ behavioural difference between male and female which is constructed socially, i.e. the differences which are not God's decision or nature, but created by human beings (men and women) through a long social-cultural process [3].

As a term which is discovered in a Western context, gender is brought by feminism. However, it becomes an approach which is globally able to enter social-political spaces in every country in the world. Gender reminds the need of integrating the experiences among the poor society or non-white skinned women into religious patriarchy analysis [4]. That is the new history in the world of women who asked for gender equality. The difference between men and women in the world, in the context of gender is not traditionally defined as the antagonism of men-women, but an admittance of differences which are among women themselves. As those aspects do not eliminate each other, but are continuously sharpened as the strength of female political decision making. Gender is not westerncentred because it is just a "turning point" which gets around with regional or community socio-cultural experience, whether religious or political community in certain time span.

\section{Object of the Research}

The election of Tegal Regent becomes the object of this research by analysing democracy practice which is strengthening the religiosity in selecting Umi Azizah who is a woman as well as the political actors of female movement. Democracy which gives spaces for contesting women with religion values and also the winning of Umi Azizah are certain interests for the writers. Moreover, Umi Azizah is chosen because of a crucial condition; replacing Ki Enthus Susmono who passed away only 10 days before the registration at $K P U$. However, Umi Azizah was able to pass through the election time by a great winning.

\section{Methodology}

This research is based on the observations and the documentation of transcripts happening in the field since the declaration of Ki Enthus Susmono-Umi Azizah as the candidate of Tegal Regent - Vice Regent by PKB and supported by NU Tegal at the plenary meeting, the declaration of Umi Azizah as the candidate of Tegal Regent replacing Ki Enthus Susmono, until the declaration of Umi Azizah as Tegal Regent. Although NU is not a political party, in the context of Tegal Regent election, it has significant and strategic roles.

\section{Discussion}

Three days after the candidate of Tegal Regent, Ki Enthus Susmono passed away, Umi Azizah was predicted replacing Ki Enthus. Umi Azizah became the candidate of Tegal Regent. The crucial problem was in the place of the candidate of Vice Regent. Some names were listed to be the candidate of Vice Regent. Such as KH. Was'ari (The Chief of Tanfidz NU Tegal), Firman (Ki Enthus' son), H. Romli (NU member who is an entrepreneur), Mashadi Zaeni (The Commander of Banser Tegal). Unexpectedly, the choice went to Sabilillah Ardie (Bahrudin Nasori's son, Indonesian Parliamentary member). At this point, Umi Azizah's skill in answering the challenge was tested. As a woman, the resistances came from the political rivals claiming religious issues to decrease her electability. After all, some of those names, who did not become the candidate of Vice Regent, gave full support to Umi Azizah-Sabilillah Ardie. Mashadi Zaeni, as the commander of Banser stated 
his support for Umi Azizah-Sabilillah Ardie “One command, One instruction!” Even, a disciplinary warning was given to the members who do not follow his instruction.

After having done with her internal supporter, Umi Azizah faced a massively patriarchal black campaign. Patriarchal problem should necessarily be counted, realizing that the society still strongly follow the values of patriarchal culture which are not conducive for the effort of the enforcement of female rights. The worse, that culture is claimed from the religious study.

There are some indicators:

First, the society still believes in the statement which gives preference based on sex. Men, in any aspect, are always being special than women. Boys are given special position in front of girls. This thought has been fixed in the society and brought in every aspect of life, such as education, economy, and politics even in understanding a religion.

Second, the society still has a stereotype to see that women are weak, fragile, and passionate. The society tends to see women from their physical appearance and posture, i.e. having a weak body, small, and powerless, although some research has proven that women in many fields can be stronger, more diligent, more precise, and more resistant to stress. This mislead point of view, then, gets a justification from a religious value which states that women are not strong in their religion and logic (al-mar'ah naqishah fi al-aql wa al-din)

Third, the society still perceives that pregnancy and giving a birth are women's natures. So that, the suffer, the pain, even the death felt by women is as a result of their reproduction functions which are the natures that should be felt by women [5].

There are some identifications placing women in a frame which is not better than men (Nasarudin Umar, 2001: 43)

Table 1. Comparation between Man (Masculine) and Women (feminine)

\begin{tabular}{|c|c|c|}
\hline No & Man (masculine) & Woman (feminine) \\
\hline 1. & Very aggressive & Less aggressive \\
\hline 2. & Independent & Less independent \\
\hline 3. & Less emotional & More emotional \\
\hline 4. & Easily hide emotion & Difficult to hide emotion \\
\hline 5. & More objective & More subjective \\
\hline 6. & Not easily influenced & Easily influenced \\
\hline 7. & Less submissive & More submissive \\
\hline 8. & Keen on exact subject & Not so keen on exact subject \\
\hline 9. & Less fragile & Fragile \\
\hline 10. & More active & More passive \\
\hline 11. & More competitive & Less competitive \\
\hline 12. & More logical & Less logical \\
\hline 13. & Less home oriented & Home oriented \\
\hline 14. & More skilful in business & Less skilful in business \\
\hline 15. & More open-minded & Less open-minded \\
\hline 16. & Understand more about worldwide & Understand less about worldwide \\
\hline 17. & Not easily offended & Easily offended \\
\hline 18. & Adventurous & Less adventurous \\
\hline 19. & Can solve the problem & Difficult to solve the problem \\
\hline 20. & Less cry & More cry \\
\hline 21. & Commonly being a leader & Uncommonly being a leader \\
\hline 22. & Confident & Less confident \\
\hline 23. & Pro aggressiveness & Against aggressiveness \\
\hline 24. & More ambitious & Less ambitious \\
\hline 25. & Easily to use logic & Difficult to use logic \\
\hline
\end{tabular}




\begin{tabular}{|l|l|l|}
\hline 26. & Independent & Less independent \\
\hline 27. & Not awkward in appearance & More awkward in appearance \\
\hline 28. & Better thought & Worse thought \\
\hline 29. & More talkative & Less talkative \\
\hline
\end{tabular}

However, the conceptualization is not wholly correct in the context of Tegal Regent Election. Umi Azizah and the female movement could build strong and sturdy solidarity. Muslimat NU, Fatayat, and other cultural movements could fulfil the masculinity criteria. They moved confidently, not be awkward in politics and the campaign, and also be aggressive. They moved in the name of female solidarity of NU. The achievement which is needed to be stated here is that there is no money politics found among the voters. On the contrary, the female participants build their strength voluntary. I witness by myself that a female activist of Muslimat $N U$ paid the pedicab which was rented to pick mature voters to vote for Umi Azizah by herself.

\section{Conclusion}

From the explanation above, the writer concludes that democracy gives space for woman to be a leader not against with the religious value of Islam. NU as an authoritative institution in the Islamic field does not matter as long as to achieve everyone goal. In the context of Tegal Regent Election, the chance got by Umi Azizah as the representative of women political movement achieved a great goal. It is not only $70,94 \%$ votes, but also as a medium to educate the society about politics. Moreover, it can prevent the practice of money politics.

\section{References}

1. Khutbah Iftitah KH. Chambali Usman as a Rois Syuriah NU Kabupaten Tegal on Halaqah 999 Ulama at Tegal Regency.

2. Komisi Pemilihan Umum (KPU) Tegal Regency.

3. Kantor Menteri Negara Urusan Peranan Wanita, Buku III: Pengantar Teknik Analisa Jender, 1992

4. Dr. M. Fakih, Analisis Gender dan Tranformasi Social, (Pustaka Pelajar; Yogyakarta, 2001)

5. P. Connolly, Aneka Pendekatan Study Agama, (LKiS, Yogyakarta, 2002)

6. M. Mulia, Muslimah Reformis, (Mizan, Bandung, 2004) 